\title{
REMARKABLE BRIDGE CONSTRUCTIONS WITHIN THE REGIONAL DIRECTION OF ROADS AND BRIDGES TIMISOARA
}

\author{
Cristian - Ilie ISPRAVNIC ${ }^{1}$ \\ Anamaria Ramona RADOMIR ${ }^{2}$
}

UDK: 624.21(498)

\section{DOI: 10.14415/konferencijaGFS2019.024}

Summary: The Regional Directorate of Roads and Bridges Timisoara (founded in 1951), operates in the western part of the country, in the Alba, Arad, Caras-Severin, Gorj, Hunedoara, Mehedinti and Timis counties, managing a national road network with a length of more than $2.000 \mathrm{~km}$, on which 680 bridges are situated.

Some of these are structures with long-term exploitation, true works of art, emblematic on the territory of the respective localities.

The paper presents an overview of art constructions from DRDP Timişoara, with some remarkable examples.

Keywords: construction, long-term exploatation, bridges

Between the transport infrastructure of a region and its economic development there is a biweekly relationship. From ancient times, the most prosperous regions have been either along major communication routes or at their intersection. The development potential of a region is even greater as that region has a more developed transport infrastructure. Undoubtedly, transport infrastructure is among the most important factors of national or regional economic competitiveness, alongside fiscal, technological and research infrastructure or the level of workforce training. Reciprocal relationship is also valid. Economic growth leads to an even greater increase in transport needs, creating additional pressure on existing infrastructure. Symmetrically, the lack of adequate transport infrastructure can stifle development, and the regional economy is stagnating or even regressing.

Difficult access (measured in time and cost) to economic, residential or leisure areas of a region makes the region less attractive for both the business and the public.

The construction and maintenance of transport infrastructure are activities with a strong multiplier effect, creating many jobs and boosting economic development on a horizontal basis. The construction sector, the construction materials industry, the metallurgy industry, the machinery and construction machinery industry and the design services are the economic areas that most benefit from infrastructure investments.

\footnotetext{
${ }^{1}$ Cristian Ilie Ispravnic, Dipl. Eng Regional Directorate of Roads and Bridges, Timisoara, Romania

${ }^{2}$ Anamaria Ramona Radomir, PhD dipl.eng. University Politehnica of Timisoara, Regional Directorate of Roads and Bridges Timisoara, telephone: +40799000899 e-mail:radomir_anamaria@yahoo.com
} 
Савремена достигнућа у грађевинарству 23-24. април 2019. Суботица, СРБИЈА

The level of development and the state of the transport infrastructure are also a strong influence on tourism activity. Numerous studies have highlighted the close link between transport development and tourism development.

Ensuring access to tourist areas and creating rapid connections between regional transport infrastructure on the one hand and national and European transport buses on the other hand are indispensable conditions for the development of the potential of national and regional tourism.

In the last decades, traffic on national roads has grown spectacularly, both in terms of number of vehicles and axle weight. The bridges were designed at standard convoys, Class I (A30 and V80 heavy duty vehicles). At present, these loads are overtaken, with lorries weighing more than 30 tons.

In fact, the new Eurocode 1 European norms, which are mandatory in our country, require increased loads. Starting from the real traffic measured at the Nadlac border (type of trucks, number of passes and axle weight), it is proposed to establish the operational safety of these structures.

For actual convoys passing on road bridges, reinforced concrete and metal, the degree of fatigue can be established, with the Langer - Miner principle, methodology adopted by the European norms EUROCOD.

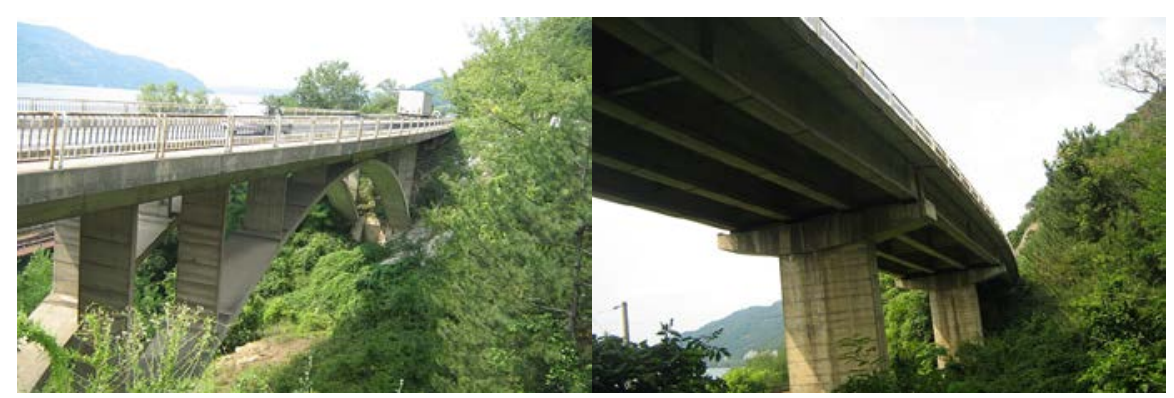

Figure. 1. Viaduct on DN 6 km 358+268; $\mathrm{km} \mathrm{358+720}$

Currently, checking existing structures is one of the most important issues for design engineers. Most existing bridges, both by rail and by road, which were built at the beginning of the last century, have reached a considerable life span, thus establishing the safety of operation of these structures becomes a priority for contemporary society. Most bridges with high lifespan are still in operation after having undergone multiple structural interventions (repair and consolidation work) due to so many structural variations and due to the need to adapt to the new conditions of traffic. In addition to the classical method of linear cumulative damage, a new analysis based on the principles of rupture mechanics is proposed. 
Contemporary achievements in civil engineering 23-24. April 2019. Subotica, SERBIA

\section{TECHNICAL STATE OF EXISTING BRIDGES}

The communications infrastructure in our country and other Eastern European countries is 70 to 90 years old. Many of these structures are kept in circulation after a series of repairs and consolidations.

The rehabilitation and maintenance of existing bridges for their maintenance in operation is one of the most important problems today. Replacing them with new structures raises financial, technical and political issues.

During the operation the bridges are subject to degradation, because in the last decades the volume of traffic has increased, and a continuous maintenance for ensuring the safety of the existing bridges is especially important. In the framework of the safety assessment of bridges, the most important aspect is to carry out a careful inspection of the structure. In general, the life of the bridge is due to the fatigue of the material. For bridges where the request history is known, lifetime can be calculated using the regular Miner and an appropriate S-N curve. During the process of estimating the lifetime of existing bridges it is important to establish the already accumulated fatigue of the structural elements. Consequently, if the demand spectrum remains the same, no fatigue cracks will occur in the future.

\section{THE MAIN STEPS IN ESTABLISHING THE LIFETIME OF EXISTING BRIDGES}

Linear cumulation of damages caused by convoys. Theoretically, tear is reached when the damage becomes total.

$$
\begin{aligned}
& S=\sum \frac{n_{i}}{N_{i}} \text { where, } \mathrm{n}_{\mathrm{i}} \rightarrow \Delta \sigma i \\
& \mathrm{~N}_{\mathrm{i}} \rightarrow \Delta \sigma R
\end{aligned}
$$

The relationship between the number of $\mathrm{N}$ cycles and the stress span (Wöhler curve) is expressed by:

$$
N_{i}=\left(\frac{\Delta \sigma_{R}}{\Delta \sigma_{i}}\right)^{k} \cdot N_{R} \quad \text { where, } \Delta \sigma_{R} \text { represents the voltage span at NR }=2 * 106 \text { cycles, }
$$

multiplied with the safety coefficient $1 / \gamma R(\Delta \sigma R / \gamma R) . \Delta \sigma_{R}$ represents the stress span at a number of $\mathrm{Nj}$ cycles.

The authors propose a complementary method for assessing the remaining life of existing bridge structures based on the basic concept of mechanics: $\mathrm{JI} \leq \mathrm{JIC}$ In practice, two situations are recorded, namely:

$\S \mathrm{D}<0,8$ the probability of cracking is reduced. Intervals between two successive inspections (generally between 3 and 6 years) can be established on independent tiredness criteria. However, particular attention will be paid to critical details.

$\S \mathrm{D} \geq 0.8$ the occurrence of cracks is probable and possible. 
Савремена достигнућа у грађевинарству 23-24. април 2019. Суботица, СРБИЈА

The methodology based on the principles of rupture mechanics is conceived as a complete, two-step analysis of structural elements containing fatigue defects, namely: Step 1 comprises a first step in determining the acceptability of defects detected in the structure based on an analysis that has at its core the breakdown evaluation diagrams, respectively the final accepted values of the dimensional defects studied are based on the tear strength of the material and the second step includes a fatigue assessment of the structural elements analyzed based on the actual traffic records flowing through the bridge, of the initial and final dimensions of the defects and the parameters of the breakage mechanics that characterize the crack progression, for example the material constants. This second stage is required because the bridge structures are subjected to repetitive loads under which the defects detected and evaluated as acceptable are increased until the element breaks. Under these circumstances, it is important to know the length of time that the bridge can be safely operated (years, months, days).

Structure verification: Given the importance of the structure, if the verifications were carried out, the following two steps are proposed:

The fatigue evaluation of the structure based on the linear cumulative rule of the Palmgreen - Langer - Miner Damage.

In this respect, a systematization of traffic on the bridge is difficult to carry out, but an approximate assessment can be made.

\section{CASE STUDY}

The bridge over the Strei River from km 376 + 818 is located in Simeria Veche, Hunedoara County.

At construction (1950), the bridge with a 7.00 m roadway was sized to a convoy equivalent to Class I loading, and at rehabilitation (1997), the bridge was reinforced by an overspray plate and enlarged to $7.80 \mathrm{~m}$ and therefore the bridge is in Class E loading according to STAS. Due to the lowering of the talveg, during the rehabilitation, the three piles were consolidated. The piles have direct foundations and have been reinforced by making four pillars (two upstream and two downstream), ensuring that elevations and foundations are supported by a reinforced concrete slab.

During the 16 years of rehabilitation, Strei River continued its descent, now reaching two arms, one in the opening 2 and the other in the opening 3 . In this situation, the radius of $\mathrm{P} 2$ is very exposed, being uncovered at a height of about $2.70 \mathrm{~m}$, measured in the plane of the parapet downstream. The bridge has a total length of $112.83 \mathrm{~m}$, measured in the plane of the downhill, with a length of the superstructure of $101.70 \mathrm{~m}$. In a cross section the bridge has a total width of $10.73 \mathrm{~m}$ with a road section of $7.82 \mathrm{~m}$ and two sidewalks of $0.98 \mathrm{~m}$ and, respectively, $1.05 \mathrm{~m}$. The bridge superstructure consists of two continuous beams arranged at about $5.25 \mathrm{~m}$ of interax. The width of the beams is constant with the exception of the pile areas, when it increases from $0.50 \mathrm{~m}$ to $0.80 \mathrm{~m}$. The beam height varies from $1.26 \mathrm{~m}$ to $2.87 \mathrm{~m}$ (up to weight). The beams work together through the top plate (reinforced by over-casting) and through a number of 5 strips to all infrastructures.

The technical condition of the bridge has been established according to "Technical Instructions for Establishing the Technical Condition of a Sub-Indicator A.N.D. 522 2002 "by evaluating all the quality indices (Ci) and functionality (Fi). 
Contemporary achievements in civil engineering 23-24. April 2019. Subotica, SERBIA

- Technical Status Score: $\mathrm{C}=\Sigma \mathrm{Ci}=\mathrm{C} 1+\mathrm{C} 2+\mathrm{C} 3+\mathrm{C} 4+\mathrm{C} 5$

- Functionality Quality Index: F = $\mathrm{Fi}=\mathrm{F} 1+\mathrm{F} 2+\mathrm{F} 3+\mathrm{F} 4+\mathrm{F} 5$

- The general technical condition of the bridge is expressed by the technical status index (Ist): Ist $=\Sigma \mathrm{Ci}+\Sigma \mathrm{Fi}$

At this work Ist $=39$, the bridge belonging to the IV class of technical condition, unsatisfactory condition.

The indices that led to the determination of the total quality label have the following values:

- the quality indices of the technical state $\Sigma \mathrm{Ci}=8$; $\quad$ - functional indices $\Sigma F i=31$

DN 7 provides the connection between Deva and Sebeş and at $\quad \mathrm{km} 376+818$ cross the Strei River on a reinforced concrete bridge with four openings, two 30,10 m and two 22,20 m long. The static diagram of the bridge is a continuous beam.

The national road 7 (DN 7), Sebeş - Deva, is classified as a European national road (E 68), according to the order of the Minister of Transport no. 43 / 27.01 .1998 and is the most important road link for the Central and Western European countries. Traffic across the road sector is very high, and the percentage of heavy vehicles is important.

The bridge across the Strei River from km $376+818$ is located in the vicinity of Simeria Veche, Hunedoara County, the latter being on the right bank of the river.

\begin{tabular}{|c|c|c|c|c|c|c|c|c|c|c|c|}
\hline DN 7 & Simeria & Band 1 & & & & & & & & & \\
\hline $\begin{array}{l}\text { Calculated } \\
\text { parameter }\end{array}$ & A2 & A2R1 & A2R2 & A2R3 & A3R2 & A3R3 & A2S1 & A2S2 & A2S3 & A3S2 & A3S3 \\
\hline $\begin{array}{l}\text { Number of } \\
\text { vehicles }\end{array}$ & 22822,0 & 20,0 & 444,0 & 472,0 & 1924,0 & 1304,0 & 126,0 & 12884,0 & 41020,0 & 472,0 & 538,0 \\
\hline $\begin{array}{l}\text { Total weight } \\
\text { (t) - mean }\end{array}$ & 6,5 & 17,3 & 18,5 & 21,5 & 30,4 & 36,5 & 13,6 & 15,7 & 25,4 & 24,3 & 27,5 \\
\hline $\begin{array}{l}\text { Total weight } \\
\text { (t) - maximum } \\
\text { Total weight }\end{array}$ & 20,0 & 22,0 & 35,0 & 41,0 & 56,0 & 64,0 & 24,0 & 35,0 & 58,0 & 47,0 & 61,0 \\
\hline $\begin{array}{l}\text { (t) - no of } \\
\text { overflow }\end{array}$ & 8,0 & & & 2,0 & 258,0 & 564,0 & & & 3412,0 & 4,0 & 52,0 \\
\hline $\begin{array}{l}\text { Weight on } \\
\text { axle } 1 \text { - mean }\end{array}$ & 3,0 & 6,5 & 5,0 & 5,4 & 6,2 & 6,5 & 4,9 & 5,0 & 5,3 & 5,9 & 5,2 \\
\hline $\begin{array}{l}\text { Weight of axle } \\
1 \text { - maximum }\end{array}$ & 9,8 & 8,0 & 7,7 & 8,6 & 9,5 & 10,0 & 6,2 & 8,4 & 9,4 & 9,1 & 6,9 \\
\hline $\begin{array}{l}\text { Weight on } \\
\text { axle } 2-\text { mean } \\
\text { Weight on }\end{array}$ & 3,9 & 6,0 & 7,4 & 6,8 & 7,6 & 7,7 & 4,1 & 5,5 & 6,9 & 6,3 & 4,3 \\
\hline $\begin{array}{ll}\text { axle } & 2 \\
\text { maximum }\end{array}$ & 14,7 & 11,3 & 13,3 & 10,5 & 14,4 & 14,2 & 9,5 & 13,0 & 17,0 & 10,9 & 12,8 \\
\hline $\begin{array}{l}\text { Weight on } \\
\text { axle } 2-\text { no of } \\
\text { overflow }\end{array}$ & 53,0 & 1,0 & 13,0 & 2,0 & 217,0 & 244,0 & & 241,0 & 3487,0 & 9,0 & 2,0 \\
\hline Weight on axle & e 3 - mean & 5,2 & 3,4 & 3,8 & 5,9 & 7,4 & 4,9 & 2,8 & 4,4 & 4,9 & 4,5 \\
\hline $\begin{array}{l}\text { Weight on ax } \\
\text { maximum }\end{array}$ & $3-$ & 8,1 & 9,0 & 8,7 & 14,4 & 13,5 & 9,5 & 9,5 & 12,2 & 10,2 & 12,6 \\
\hline
\end{tabular}

Table 1. Results of Weighing of Heavy Vehicles 


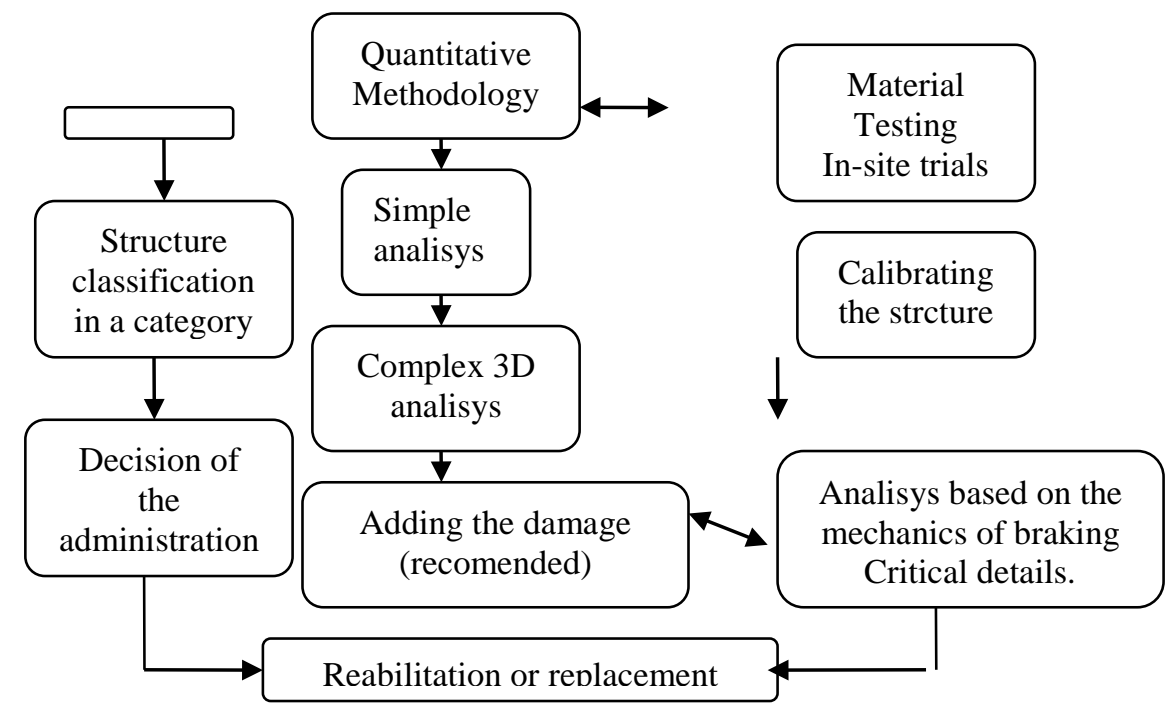

Figure 2. Methodology for verification of existing road bridges

\section{CONSOLIDATING THE AFFECTED BRIDGE}

Increasing congestion loads with increased traffic may lead to a need in what is building bridges. These things generally have a unique character, involving a certain degree of responsibility and are very complex. In carrying out such consolidations, as a first step, consists in drawing up special documents, which must include the following parts:

- Listing in detail the defects found and possible remedies;

- The data to be collected from the field when "in situ" is attempted for the structure;

- The age of the respective bridge, any previous consolidation work, a detailed history or at least a summary of the requests;

- The convoy in which consolidation will be carried out.

The designer will calculate the efficacy to prove that the repair can be indicated, not the replacement of some bridge components. Consolidating, in principle, an existing metallic sheet can no longer be effective if the value of the work needed exceeds 40 percent of the value of a new structure.

On this occasion, it is underlined that a bridge that is actually consolidated does not represent a new bridge, but its operating life is limited for a period of 20 to 40 years. Consolidations will be made during capital repairs, generally by consolidating it is assumed to increase the load capacity. It is worth mentioning that a deck can have two or more repairs, which is very rare, the repairs being capital, but it will not be admitted twice that the same piece is reinforced.

Efforts that are introduced in the section of bars or elements that exceed the permissible standards can be diminished if the section is to be used with new parts, new material, which will represent direct reinforcement or new structural elements in the metal construction already existing, which can reduce the efforts of the existing structure, thus representing indirect consolidation. 
Contemporary achievements in civil engineering 23-24. April 2019. Subotica, SERBIA

As a check of the number of vehicles weighed in a year, as well as number of passes for A2S3, A2R2, A2 for each month, Nadlac customs, inputs + outputs.

Vehicles type A2S3, (At)

2 axles and (S) 3 axles

Vehicles type A2R2, (A) 2 axles and (R) 2 axles, having different configurations
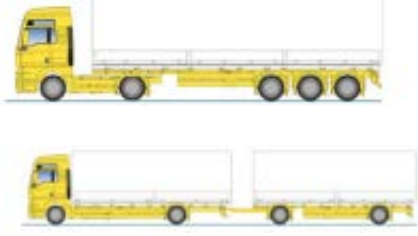

Vehicles A2 (A) 2 axles

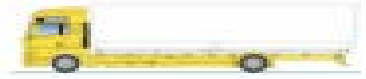

Road traffic is the main reason for road damage, especially on high-traffic roads. Every vehicle passing on a road causes a very small but significant momentary deformation of the structure. Passage of several vehicles has a cumulative effect which gradually leads to permanent deformations and damage to the road surface.

Research has, however, shown that light vehicles, such as cars and light commercial vehicles, contribute relatively little to the deterioration of the road structure compared to heavy vehicles. In addition, the load carried by each axle of the heavy vehicle determines its destructive effect.

\section{THE EFFECTS OF THE PRESSURE OF THE TIRES ON THE ROADS}

Increased tire pressures increase the demand for contact on the tire-road interface. Recent research by CSIR indicates that measured vertical contact stresses exceed the inflation pressure of the tire by about 30\%. On the other hand, under-swollen overloaded tires can result in contact stresses that exceed the tire inflation pressures of 2 to 3 times. The degree of road damage caused by overfilled or sub-inflated tires may be as much or even greater than the degree of damage caused by heavy-duty vehicles overloaded with correctly inflated tires. It is therefore essential that the tires are inflated according to the manufacturer's specifications for optimum loading / inflation pressure and that the legal loading limits for axles for roads and bridges must be complied with in accordance with axle load regulations.

Certain configurations of heavy goods vehicles are more "circulating" than other configurations in terms of relative damage per tonne of cargo carried.

The first systematic attempt to quantify the relationship between axle load and road damage was made as part of a complex road experiment (known as the AASHO road test). The experiment allowed vehicles with different axle loads to travel along different sections of the road and compare the number of load repetitions applied on the road before reaching a defined level on the structure. Applying the Equivalence Factor F converts all axle loads and vehicle configurations into an equivalent number of standard axles. This relationship indicates, for example, that a single four-wheel axle load which is only $25 \%$ of the legal load limit of 9 tonnes, ie 11,25 tonnes, is equivalent to the standard axle loads of 3,8 has 2, 6 times the damaging effect on the road of a legal 9 tonne. 
Савремена достигнућа у грађевинарству 23-24. април 2019. Суботица, СРБИЈА

\begin{tabular}{|c|c|c|c|c|c|c|c|c|c|}
\hline \multirow{2}{*}{$\begin{array}{l}\text { Auto } \\
\text { type }\end{array}$} & \multirow{2}{*}{$\begin{array}{c}\text { No of } \\
\text { vehicles }\end{array}$} & \multicolumn{7}{|c|}{ Mean weight on axles } & \multirow{2}{*}{$\begin{array}{c}\text { Total } \\
\text { mean } \\
\text { weight }\end{array}$} \\
\hline & & $\begin{array}{c}\text { Axles } \\
1\end{array}$ & $\begin{array}{c}\text { Axles } \\
2\end{array}$ & $\begin{array}{c}\text { Axles } \\
3\end{array}$ & $\begin{array}{c}\text { Axles } \\
4\end{array}$ & $\begin{array}{c}\text { Axles } \\
5\end{array}$ & $\begin{array}{c}\text { Axles } \\
6\end{array}$ & $\begin{array}{c}\text { Axles } \\
7\end{array}$ & \\
\hline A2 & 5,985 & 6.19 & 5.10 & & & & & & 11.29 \\
\hline A2R1 & 150 & 3.71 & 5.81 & 5.21 & & & & & 14.73 \\
\hline A2R2 & 7,680 & 6.57 & 9.57 & 6.56 & 6.68 & & & & 29.38 \\
\hline A2R3 & 810 & 7.36 & 9.83 & 7.46 & 6.34 & 5.29 & & & 36.27 \\
\hline A2S1 & 96 & 6.40 & 7.57 & 7.68 & & & & & 21.65 \\
\hline A2S2 & 396 & 6.90 & 7.98 & 6.32 & 6.08 & & & & 27.28 \\
\hline A2S3 & 149,06 & 7.08 & 9.29 & 6.18 & 6.21 & 6.04 & & & 34.80 \\
\hline A2S4 & 4,290 & 7.15 & 9.17 & 6.22 & 7.20 & 5.29 & 5.69 & & 40.72 \\
\hline A3 & 456 & 6.74 & 8.01 & 3.74 & & & & & 18.49 \\
\hline A3R2 & 960 & 7.04 & 8.45 & 5.38 & 6.62 & 6.55 & & & 34.04 \\
\hline A3R3 & 450 & 7.16 & 7.99 & 6.46 & 6.32 & 5.12 & 5.13 & & 38.19 \\
\hline $\bar{A}$ A3S2 & 5,610 & 6.80 & 5.80 & 9.29 & 7.81 & 7.72 & & & 37.41 \\
\hline A3S3 & 1,080 & 6.75 & 5.77 & 7.31 & 5.57 & 5.41 & 4.86 & & 35.67 \\
\hline A3S4 & 2,340 & 7.21 & 6.68 & 7.16 & 6.65 & 6.66 & 6.09 & 6.11 & 46.55 \\
\hline A4 & 336 & 7.61 & 1.28 & 2.44 & 2.17 & & & & 13.50 \\
\hline A4R3 & 570 & 7.00 & 7.42 & 7.24 & 9.04 & 8.74 & 9.72 & 9.60 & 58.76 \\
\hline
\end{tabular}

Table 2. Traffic Nădlac + Nădlac II, May - June 2018

\section{CONCLUSIONS AND RESULTS}

The destructive effect of heavy convoy traffic on bridges is significant in the context of establishing the best road structures based on all road categories. The aggressiveness of heavy convoys to bridge structures is determined by the conversion of traffic into equivalent axles, having as a mean the equivalence coefficients.

The maximum permissible loads as well as the tendency for the various categories of heavy vehicles, namely the frequency of their overloading, highlight the importance of the traffic parameter for the dimensioning of structures in order to reduce the cost of road infrastructure road.

As a measure, the following were taken, in view of the risk that a damaged bridge could give. For the estimation of the operational safety of the existing bridges, a unique methodology is needed which includes cumulation of damages and the concept of rupture mechanics.

The findings of the study can be extended to other countries in central and south - eastern Europe, where the technical state of existing bridges is similar.

The economic growth recorded in recent years, mainly in the construction sector, has led to the emergence of heavy aggressive traffic with heavy-duty vehicles, with negative effects on the national road network (for example the effect of crossing a sector of the road produced by an articulated vehicle - for which the maximum permissible mass is $40.0 \mathrm{t}$, equivalent to the one produced by the passage of 5 buses or 11 MTMA vehicles of $7.5 \mathrm{t}$ or 275.000 cars).

The above mentioned are, in fact, the main arguments put forward in favor of the need to protect the road infrastructure existing by the increasing aggression of road traffic.For the 


\section{$7^{\text {th }}$}

INTERNATIONAL CONFERENCE

Contemporary achievements in civil engineering 23-24. April 2019. Subotica, SERBIA

investigation and inspection of infrastructure and superstructure elements, but also for intervention and remedial works of degradation, the Regional Directorate of Roads and Bridges Timisoara has the MOOG type bridge inspector.

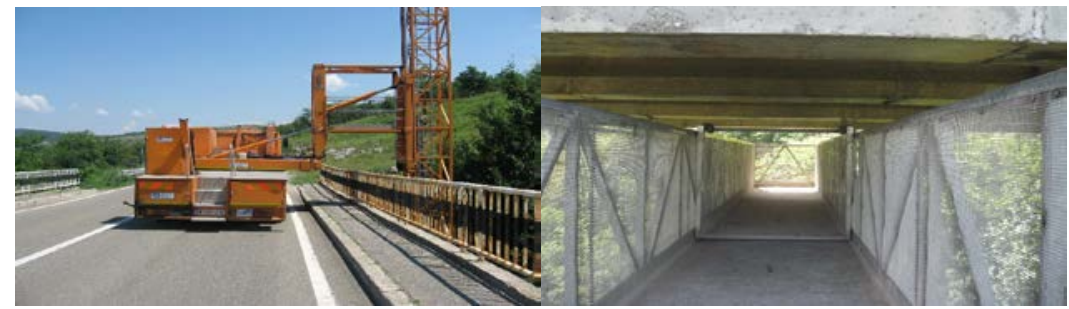

Fig. 2. (a) MOOG type bridge inspector (b) The working platform of the MOOG bridge inspector.

\section{REFERENCES}

1.Pearson, R A, „Effects of overloading on roads“

2.Radu B, Dorel B., Edward P, "Dezvoltarea sustenabilă și reabilitarea podurilor din vestul țării“", 2005

3.Regional Directorate of Roads and Bridges Timisoara, technical library, 2018 